\title{
Blooms of the dinoflagellate Glenodinium sanguineum obtained during enclosure experiments in Lake Tovel (N. Italy)
}

\author{
Marco CANTONATI*, Massimiliano TARDIO, Monica TOLOTTI and Flavio CORRADINI ${ }^{1)}$ \\ Museo Tridentino di Scienze Naturali, Limnology \& Phycology Section, Via Calepina 14, I-38100 Trento, Italy \\ ${ }^{1)}$ Istituto Agrario di S. Michele all'Adige, Via E. Mach 1, 38010 S. Michele all'Adige (TN), Italy \\ *e-mail corresponding author: cantonat@mtsn.tn.it
}

\begin{abstract}
Freshwater red tides due to dinoflagellates are less common than their marine analogues, which are usually a serious problem and can even be toxic. This was not the case for Lake Tovel in the Adamello-Brenta Natural Park (Southern Alps, Italy), where the dinoflagellate Glenodinium sanguineum Marchesoni accumulated carotenoids (astaxanthin-like compound) and caused a spectacular and regular "summer reddening", which suddenly ceased in 1964. Today Lake Tovel is a temperate, meromictic (with dimictic mixolimnion), oligotrophic mountain lake, characterised by marked water level fluctuations. G. sanguineum is still present in the lake, although with markedly lower densities in comparison to the pre-1965 period. Enclosure studies were carried out to identify the main factors regulating the blooms. In 1998, by means of phosphorus enrichments, it was possible to obtain a marked increase in numbers of G. sanguineum. Phosphorus additions in similar enclosures in 1999, when weather conditions during the summer were not optimal (mostly cloudy with frequent rainfalls), did not have the same effect, since species known to thrive in spring or under icecover developed. In summer 2000, by attenuating light in one of the enclosures, it was shown that irradiance conditions strongly interacted with phosphorus availability in determining the species that dominated the phytoplankton. In summer 2001, G. sanguineum increased again in the enclosure enriched with phosphorus. Nitrogen was observed to become a limiting factor only in conditions forced by phosphorus additions. From the first four years of in situ experiments, we concluded that phosphorus and light conditions were among the key factors controlling the proliferation and the dominance of $\mathrm{G}$. sanguineum.
\end{abstract}

Key words: phosphorus, light, enclosures, Glenodinium sanguineum, Lake Tovel, freshwater red tide

\section{INTRODUCTION}

Marine red tides are usually caused by dinoflagellates and take place in warm regions or seasons and in places which are richer in nutrients, such as coastal waters influenced by agricultural activity from inland regions (e.g. Hoek et al. 1995). In freshwater environments several algal groups, such as Cyanophyta (e.g. Planktothrix rubescens (D.C. ex Gom.) Anagn. et Kom.), Chlorophyta (e.g. Haematococcus pluvialis Flotow em. Wille) and Euglenophyta (Euglena sanguinea Ehrenberg), can generate red colourings. Freshwater red tides, due to dinoflagellates, are much less widespread than in the sea (e.g. Rodriguez et al. 1999) and are mainly due to Peridinium Ehrenberg and Peridiniopsis Lemmermann taxa, which have been reported and documented particularly in Japan (Fukuju et al. 1998), Korea (Park M. H-K. personal com.), Israel (Berman-Frank et al. 1994) and France (Rodriguez et al. 1999). These environments are mostly artificial lakes (dammed reservoirs; e.g. Fukuju et al. 1998). In one case even a riverine system was involved (Leitao et al. 2001). The standing waters affected by dinoflagellate red tides are not always rich in nutrients, being most frequently mesotrophic or oligotrophic (Fukuyu et al. 1998; Park M.H-K. personal com.). In environments which are poor in phosphorus, dinoflagellates may be favoured by their high efficiency in the assimilation and retention of phosphorus (Margalef 1983). Dinoflagellates have complex life cycles that are regulated by environmental factors, such as temperature, nutrients and light (e.g. Park \& Hayashi 1993).

The influence of these environmental factors on the development of phytoplankton communities can be studied in situ by means of enclosures (e.g. Wilcox \& DeCosta 1982; Mitchell \& Malthus 1984; Hein \& Riemann 1995; Halac et al. 1997). For instance, Jacobsen et al. (1995) were able to show the effects of increased nitrate and phosphate concentrations on a spring bloom by conducting mesocosm experiments, and Vinebrooke \& Leavitt (1999) showed the effects of UV radiation on shallow water communities (including phytoplankton) of an alpine lake. This mesocosm technique has the great advantage of allowing one to work in the natural environment, rather than trying to culture the organisms, which are difficult to grow and to produce significant biomass.

Red tides, due to dinoflagellates in lakes, are usually a serious problem and countermeasures are often taken, since they can be toxic, can cause foul odours and taste and reduce the aesthetic value of these environments (e.g. Fukuju et al. 1998). This was not the case of Lake Tovel in the Brenta Dolomites (Italian Alps), where regular summer blooms of Glenodinium sanguineum Marchesoni, which accumulated carotenoids (astaxanthin or a very similar compound; Gerosa 1966, Guella pers. com.), gave a spectacular "reddening of the 
waters" of the South-West Bay (called Red Bay)). The first occurrence was reported in 1875 (Bolognini 1877). No toxic effects were ever mentioned and on the contrary the brightness and intensity of the red colour attracted tourists and scientists. The phenomenon can be considered unique because of its regular appearance in summer, with the sole exception of years with very bad weather in the summer months (Marchesoni 1959). The lake is located in a beautiful mountain valley (today in the Adamello-Brenta Natural Park), which in the past has been affected only by wood cutting, cattle breeding and the building of cottages and mountain huts around the lake (a drain trunk line was built and became active only in the early 70s). The sudden ceasing of the reddening phenomenon in 1965 caused a lot of concern and many hypotheses were proposed to explain the disappearance of the blooms (e.g. Tomasi 1989). In our opinion the most plausible theories refer to changes in the nutrient status of the lake. To explain the end of the reddening phenomenon, Dodge (1970) hypothesised that nutrient status could have gradually changed due to changes in the land use in the Tovel Valley. In a popular article Aregger Perini (1968) wrote that it is likely that the reddening phenomenon arose when all available nitrogen in the water was exhausted. Several other hypotheses on the disappearance of the phenomenon refer to the influence of some pollutant. In particular Fuganti \& Morteani (1999) found 14 types of herbicides in little amounts in the exposed sediments (during winter) of the "Red Bay" and concluded that this may be the cause of the end of the reddening, admitting however, that the specific sensitivity of $G$. sanguineum to these products has not been demonstrated. Paganelli et al. (1981) observed that, due to a changed distribution of rain events throughout the year in the last decades, unlike in the past, the surficial outlet is active also in the summer months and this causes the loss of warm surface water from the epilimnion of Lake Tovel. In a more recent review paper, Paganelli (1992) states that Lake Tovel presents a very dynamic hydrological regime, which he even defines "fluvial-lacustrine".

Since 1997 we have conducted enclosure investigations in Lake Tovel. Different types of these experimental structures were tested and compared (Cantonati et al. 2002). The present paper is based on a selection of the results obtained with these experiments with the objective to focus on the influence of phosphorus and light conditions on the dominance of $G$. sanguineum within the phytoplankton community and on its numerical increase.

\subsection{The study environment}

Lake Tovel $\left(1178 \mathrm{~m}\right.$ a.s.l., $\mathrm{z}_{\max }=39 \mathrm{~m}$, surface $=$ $382,500 \mathrm{~m}^{2}$ ) is a temperate, meromictic, oligotrophic mountain lake, characterised by marked water level fluctuations. The lake includes a $39 \mathrm{~m}$ deep main basin (NE) and a shallow (about $5 \mathrm{~m}$, surface about 70,000 $\mathrm{m}^{2}$ ) SW-basin (Red Bay). The mixolimnion shows a dimictic behaviour, mean Secchi disk value is about 10 $\mathrm{m}$ and the distribution of algal nutrients $\left(\mathrm{TP}=3-6 \mu \mathrm{g} \mathrm{l^{-1 }}\right.$, $\mathrm{N}-\mathrm{NO}_{3}=280-420 \mu \mathrm{g} \mathrm{l}^{-1}, \mathrm{SiO}_{2}=0.4-1.4 \mathrm{mg} \mathrm{l}^{-1}$; Corradini et al. 2001) in the euphotic zone (found to reach $14-23 \mathrm{~m}$ depth by seasonal measurements with a LICOR quantum sensor, Cantonati unpubl.) is even. Phosphorus was shown to be the factor limiting primary production by Cordella et al. (1981). According to the most recent hypotheses, Lake Tovel originated from the melting of dead ice after the end of the last glaciation. This first lake was however much smaller (only $18 \mathrm{~m}$ deep). At the end of the Sixteenth Century the slumping of material from the right slope of the valley caused a rise in level of about $21 \mathrm{~m}$ (Oetheimer 1992).

\section{METHODS}

The enclosure experiments considered were carried out in the south-western shallow Red Bay of Lake Tovel from 1997 to 2001. Mesocosms were placed in different parts of the Bay: (i) in the transition zone between the main basin and the Red Bay (1997), (ii) in the gulf in the western side of the Red Bay (1998, 2000 and 2001) and (iii) at the south-western extreme of the Bay close to the shore (1999 and 2000). See Cantonati et al. (2002) for a figure with the location of the enclosures in the Red Bay.

Enclosures of two different shapes - called "Cylinders" and "Pools" - were used (Fig. 1), (see Cantonati et al. 2002 for a more detailed description). The lower part of figure 1 also summarises the characteristics of the experiments carried out from 1997 to 2001 (mesocosm type, period, etc.).

At each sampling, air temperature, cloudiness, wind and maximum depth in each enclosure were recorded. Physical and chemical parameters (water temperature, oxygen saturation, $\mathrm{pH}$, conductivity and redox potential) were measured with a Hydrolab $\mathrm{H} 20$ probe. For phosphorus enrichments, concentrated $\mathrm{Na}_{2} \mathrm{HPO}_{4}$ solutions, were added. For nitrogen additions, a $\mathrm{Mg}\left(\mathrm{NO}_{3}\right)_{2} 6 \mathrm{H}_{2} \mathrm{O}$ solution was added. In 2000 , enclosure "C" was covered with a darkening sheet, which reduced the light intensity to about $40 \%$. Alternately, in year 2001 an attempt to increase incident light was carried out using 16 neon lamps (OSRAM L 18W/77 FLUORA).

Water samples for chemical and biological analyses were taken with a 51 Patalas-Schiendler sampler at 0.5 $\mathrm{m}$ and $2.5 \mathrm{~m}$ in the cylindrical enclosures. Sampling was always effected between 9.00 and 14.00 (solar time) both to standardise the procedure and because Glenodinium sanguineum, which is known to perform daily vertical migrations, would accumulate in the surface layer during this time of the day (Baldi 1941). At the beginning and at the end of each experiment, samples for comparison were taken in the open water of the Red Bay. 


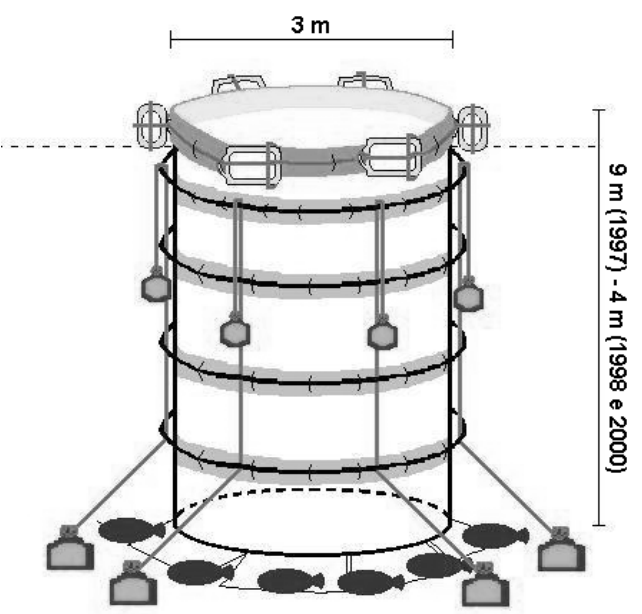

$300 \mathrm{~cm}$

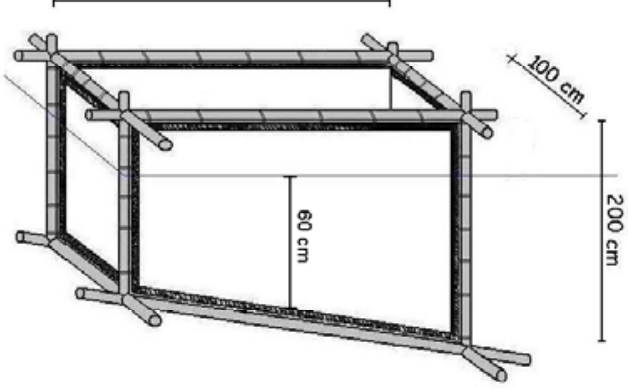

\section{Cylinder}

Material: flexible and transparent polyethylene thickness: $0.5 \mathrm{~mm}$

Dimensions: diameter $3 \mathrm{~m}$ mean water depth: $9 \mathrm{~m}$ ('97)

$3.5 \mathrm{~m}(' 98,2000$ and 2001)

capacity:

$65 \mathrm{~m}^{3}$ ('97)

$25 \mathrm{~m}^{3}(' 98,2000$ and 2001)

Open: at the top and bottom

Fig. 1. Main characteristics of the two types of enclosures (cylinders and pools) and of the experiments (period, number and type of enclosures) carried from 1997 to 2001.

Laboratory chemical analyses followed I.R.S.A. C.N.R. (1994). Nitrate-nitrogen was analysed by ionic chromatography (Dionex 120, quantification limit $=30$ $\mu \mathrm{g}^{-1}$ ) and total phosphorus by molibdate colorimetry with ascorbic acid as reducing agent after acid oxidation at $120^{\circ} \mathrm{C}$ with potassium persulphate $(5 \mathrm{~cm}$ cuvettes; quantification limit $=2 \mu \mathrm{g} \mathrm{l}^{-1}$ ).

Phytoplankton samples were fixed with Lugol's solution acidified with a $10 \%$ of acetic acid. Counts were carried out with an OLYMPUS IX70 inverted microscope according to Utermöhl (1958). At each magnification at least 100 individuals of the dominant taxon were counted, which corresponds to a maximum error of about $20 \%$ (Lund et al. 1958). Algal biovolume was calculated from linear dimensions according to Rott (1981). Water samples for chlorophyll- $a$ analyses were filtered in the field within a few hours of sampling on Whatman GF/C $0.45 \mu \mathrm{m}$ filters, which were stored at $-20{ }^{\circ} \mathrm{C}$ until the extraction in $90 \%$ acetone and the spectrophotometric analyses (Lorenzen 1967).

Air temperature and solar radiation values recorded by the meteorological station run by the Agricultural Institute of S. Michele all'Adige and available at the Internet site http://relay.ismaa.it:12164/meteo/dati.html were also considered as relevant environmental variables during data processing. Correlations among G. san- guineum and total phytoplankton biovolumes respectively and the main algal nutrients were calculated. Single classification analyses of variance were used to test for any significant difference among the averages of solar radiation, temperature and of the biovolumes of total phytoplankton and of G. sanguineum in the enclosures used as controls (labelled A) in the four years of experiments (ANOVA 1; Sokal \& Rohlf 1981).

\section{RESULTS}

The suitability of the enclosure methodology (cylindric enclosures) for the study of Lake Tovel phytoplankton and of Glenodinium sanguineum in particular was tested in the summer of 1997. Results showed that changes in the mesocosms were representative of what happened in the open water for several weeks (Tolotti \& Cantonati unpubl.).

The results of the experiments conducted from 1998 to 2001 were based on samples taken at $0.5 \mathrm{~m}$ depth. These data were used, since results obtained in 1998 showed that at the time of sampling (09.00-14.00 solar time) dinoflagellates were clearly accumulating in the upper part of the water column $(-0.5 \mathrm{~m})$, while diatoms dominated in the deeper part (-2.5 m), (Tolotti et al. 1999).

Means and standard deviations of the main physical and chemical factors are presented in table 1 . The high- 
Tab. 1. Mean and standard deviation of the main physical and chemical factors. $*=$ in this enclosure light had been artificially attenuated of about 60\%. @ = data obtained from the Internet site http://relay.ismaa.it:12164/meteo/dati.html run by the Agicultural Institute of S. Michele all'Adige.

\begin{tabular}{|c|c|c|c|c|c|c|}
\hline & \multicolumn{2}{|c|}{ Enclosure A } & \multicolumn{2}{|c|}{ Enclosure B } & \multicolumn{2}{|c|}{ Enclosure C } \\
\hline & mean & s.d. & mean & s.d. & mean & s.d. \\
\hline \multicolumn{7}{|l|}{1998} \\
\hline Air temperature $\left({ }^{\circ} \mathrm{C}\right) @$ & 16.1 & 3.4 & 16.1 & 3.4 & 16.1 & 3.4 \\
\hline Solar radiation $\left(\mathrm{MJ} \mathrm{m}^{-2} \mathrm{~h}^{-1}\right) @$ & 0.72 & 0.98 & 0.72 & 0.98 & 0.72 & 0.98 \\
\hline Water temperature $\left({ }^{\circ} \mathrm{C}\right)$ & 12.7 & 0.4 & 12.7 & 0.4 & 12.7 & 0.4 \\
\hline $\mathrm{O}_{2}(\%$ saturation $)$ & 113 & 4 & 114 & 4 & 116 & 4 \\
\hline $\mathrm{pH}$ & 8.8 & 0.08 & 8.9 & 0.08 & 9 & 0.08 \\
\hline $\mathrm{TP}\left(\mathrm{mg} \mathrm{l}^{-1}\right)$ & 10 & 4.0 & 15 & 4 & 31 & 4 \\
\hline $\mathrm{N}-\mathrm{NO}_{3}\left(\mathrm{mg} \mathrm{l}^{-1}\right)$ & 397 & 108 & 287 & 108 & 226 & 108 \\
\hline \multicolumn{7}{|l|}{1999} \\
\hline Air temperature $\left({ }^{\circ} \mathrm{C}\right) @$ & 13.8 & 3.1 & 13.8 & 3.1 & 13.8 & 3.1 \\
\hline Solar radiation $\left(\mathrm{MJ} \mathrm{m}^{-2} \mathrm{~h}^{-1}\right) @$ & 0.55 & 0.83 & 0.55 & 0.83 & 0.55 & 0.83 \\
\hline Water temperature $\left({ }^{\circ} \mathrm{C}\right)$ & 15.6 & 1.9 & 15.7 & 2.0 & 15.7 & 1.9 \\
\hline $\mathrm{O}_{2}(\%$ saturation $)$ & 102 & 3 & 105 & 4 & 109 & 9 \\
\hline $\mathrm{pH}$ & 8.6 & 0.2 & 8.7 & 0.3 & 8.7 & 0.3 \\
\hline $\mathrm{TP}\left(\mathrm{mg} \mathrm{l}^{-1}\right)$ & 16 & 9 & 32 & 10 & 40 & 12 \\
\hline $\mathrm{N}-\mathrm{NO}_{3}\left(\mathrm{mg} \mathrm{l}^{-1}\right)$ & 237 & 9 & 193 & 141 & 176 & 144 \\
\hline \multicolumn{7}{|l|}{2000} \\
\hline Air temperature $\left({ }^{\circ} \mathrm{C}\right) @$ & 12.7 & 4.2 & 12.7 & 4.2 & 12.7 & 4.2 \\
\hline Solar radiation $\left(\mathrm{MJ} \mathrm{m}^{-2} \mathrm{~h}^{-1}\right) @$ & 0.74 & 1.04 & 0.74 & 1.04 & $0.74 *$ & $1.04 *$ \\
\hline Water temperature $\left({ }^{\circ} \mathrm{C}\right)$ & 13.1 & 1.2 & 13.0 & 1.7 & 13.0 & 1.2 \\
\hline $\mathrm{O}_{2}(\%$ saturation $)$ & 116 & 4 & 127 & 9 & 132 & 13 \\
\hline $\mathrm{pH}$ & 8.6 & 0.1 & 8.8 & 0.2 & 8.8 & 0.2 \\
\hline $\mathrm{TP}\left(\mathrm{mg} \mathrm{l}^{-1}\right)$ & 6 & 2 & 31 & 11 & 42 & 21 \\
\hline $\mathrm{N}-\mathrm{NO}_{3}\left(\mathrm{mg} \mathrm{l}^{-1}\right)$ & 320 & 13 & 252 & 84 & 263 & 69 \\
\hline \multicolumn{7}{|l|}{2001} \\
\hline Air temperature $\left({ }^{\circ} \mathrm{C}\right) @$ & 15.2 & 4.2 & 15.2 & 4.2 & 15.2 & 4.2 \\
\hline Solar radiation $\left(\mathrm{MJ} \mathrm{m}^{-2} \mathrm{~h}^{-1}\right) @$ & 0.72 & 0.99 & 0.72 & 0.99 & 0.72 & 0.99 \\
\hline Water temperature $\left({ }^{\circ} \mathrm{C}\right)$ & 10.7 & 0.5 & 10.9 & 0.4 & 10.7 & 0.5 \\
\hline $\mathrm{O}_{2}(\%$ saturation $)$ & 108 & 5 & 117 & 12 & 113 & 7 \\
\hline $\mathrm{pH}$ & 8.8 & 0.1 & 9.0 & 0.3 & 8.9 & 0.2 \\
\hline $\mathrm{TP}\left(\mathrm{mg} \mathrm{l}^{-1}\right)$ & 7 & 2 & 29 & 15 & 16 & 9 \\
\hline $\mathrm{N}-\mathrm{NO}_{3}\left(\mathrm{mg} \mathrm{l}^{-1}\right)$ & 230 & 38 & 108 & 123 & 196 & 50 \\
\hline
\end{tabular}

est air temperature values were recorded in summer 1998 (mean $=16.1{ }^{\circ} \mathrm{C}$ ), the lowest in summer 2000 $\left(\right.$ mean $\left.=12.7^{\circ} \mathrm{C}\right)$. Solar radiation was similar in summer 1998, 2000 and 2001 (mean $=0.72-0.74 \mathrm{Mj} \mathrm{m}^{-2}$ $\left.\mathrm{h}^{-1}\right)$, while during summer 1999 the weather was not optimal with low irradiance $\left(\right.$ mean $\left.=0.55 \mathrm{Mj} \mathrm{m}^{-2} \mathrm{~h}^{-1}\right)$, $($ Eccel 2000). The highest water temperature values were recorded in summer 1999, (experiments were carried out close to the shore in extremely shallow waters). The highest total phosphorus values were recorded in the enclosures, which exhibited an increase in phytoplankton biovolumes: C (1998, 1999, 2000) and B (2000, 2001). The results of single classifications analyses of variance confirmed that the differences among the means of the meteorological parameters recorded in the individual years were significant (Tab. 2).

The main results are shown by the diagrams (Fig. 2), which refer to the experiments carried out in the enclosures of cylindric shape $(1998,2000,2001)$.

The species responsible for the increase, which took place in enclosure $\mathrm{C}$ at the end of the experiment of 1998, was G. sanguineum (Fig. 2). It reached nearly $100 \%$ within the phytoplankton community (Tolotti et al. 1999). During summer 2000, conditions were fa- vourable for the development of $G$. sanguineum, but only in enclosure "B" (two nutrient enrichments: phosphorus and phosphorus plus nitrogen, cf. Fig. 1).

Tab. 2. Results of a single classification analysis of variance (ANOVA1) carried out to test differences among the means of the values measured during the periods of the experiments of solar radiation, air temperature, $G$. sanguineum and total phytoplankton biovolumes in the enclosures used as controls (A).

\begin{tabular}{lcccc}
\hline & Solar rad. & Air temp. & \multicolumn{2}{c}{ Enclosures A } \\
\cline { 3 - 5 } & & & G. sanguineum & Total phytop. \\
\hline $\mathrm{F}$ & 4.410 & 9.74 & 5.91 & 15.71 \\
$\mathrm{P}$ & 0.0058 & $1.0 \times 10^{-5}$ & 0.0025 & $2.2 \times 10^{-6}$ \\
Sign. level & $* *$ & $* * *$ & $* *$ & $* * *$ \\
\hline
\end{tabular}

In enclosure "C", enriched with the same nutrients, but where light had been reduced nearly $60 \%$ by shading, the dinoflagellate Gymnodinium uberrimum (Allman) Kofoid \& Swezy developed during the central part of the experiment. The second nutrient enrichment $(\mathrm{P}+$ $\mathrm{N})$ favoured the further development of $G$. sanguineum in enclosure "B" (half way through the experiment, July $13^{\text {th }}$ ), while in " $C$ " it inhibited the development of the phytoplankton and particularly G. uberrimum. In 2001, 


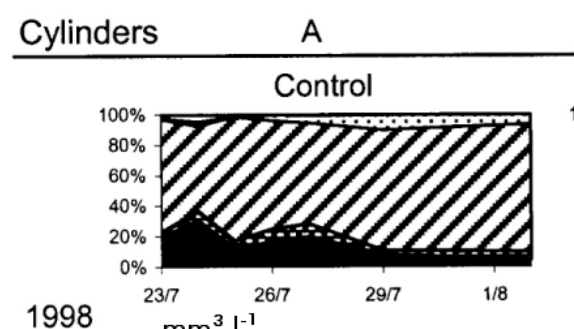

B

C
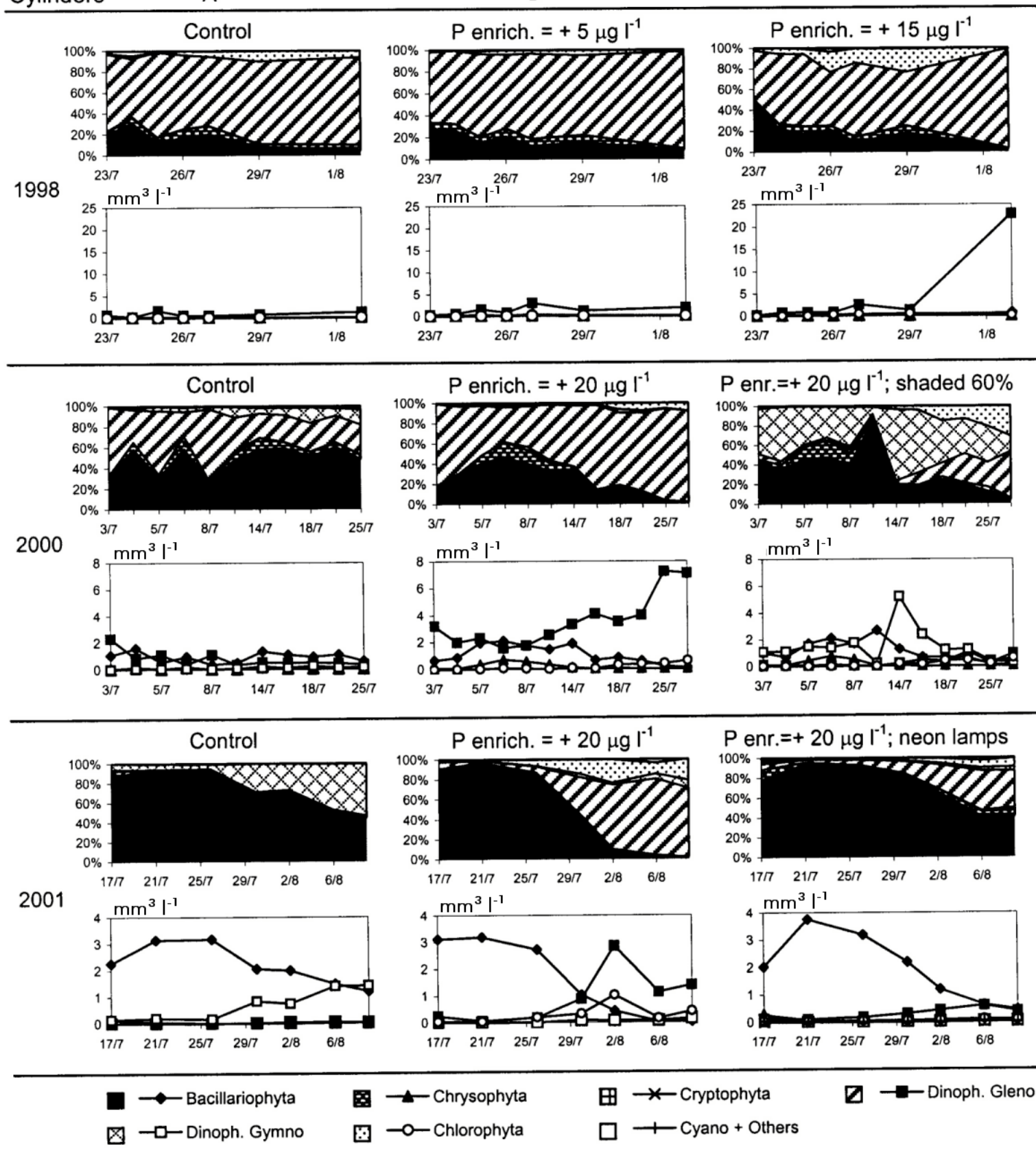

: $\rightarrow$ Chrysophyta
: 0 -Chlorophyta

田 $\rightarrow$ - Cryptophyta
$\square \rightarrow$ Cyano + Others

$\square \rightarrow-$ Dinoph. Gleno

Fig. 2. Per cent phytoplankton community composition (based on biovolumes) and absolute values of biovolumes of the main groups or taxa (Dinoph. Gymno= Gymnodinium uberrimum; Dinoph. Gleno $=$ Glenodinium sanguineum) during the experiments carried out in the cylinders.

at the beginning of the experiment all three enclosures were dominated by diatoms. The first nutrient enrichment (P) promoted Fragilaria tenera (W. Smith) Lange-Bertalot. The second phosphorus addition resulted in an increase of the phytoplankton in enclosure "B" and G. sanguineum in particular, but only until 2 August when growth became nitrogen limited (Fig. 3).

In 1999 a different type of enclosure (pools) was designed to carry out experiments in shallow and warmer near-shore waters (considered to be a habitat particularly favourable to Glenodinium sanguineum). This type of enclosure was installed in the lake again in 2000 with the intention of collecting data allowing the comparison of pools and cylinders. The main data collected in the pools are summarised in figure 4 .

The results of $t$ tests carried out between enclosures of different shapes (pools / cylinders), in different years (1999 / 2000) and with and without phosphorus enrichment are summarised in figure 4 . 


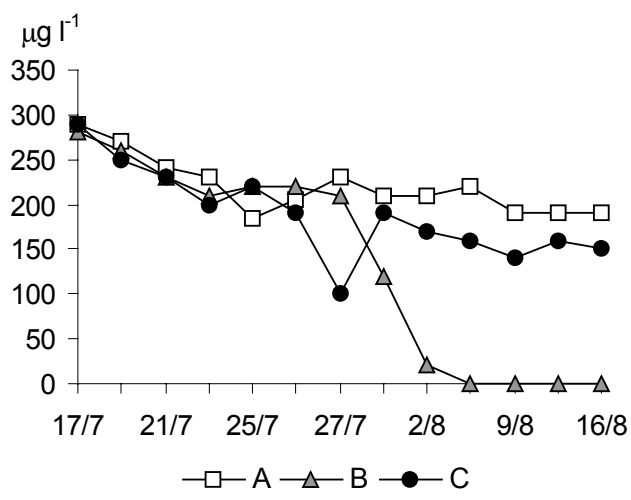

Fig. 3. Changes in the nitrate-nitrogen concentrations in the three cylinders in summer 2001.

\section{Pools}
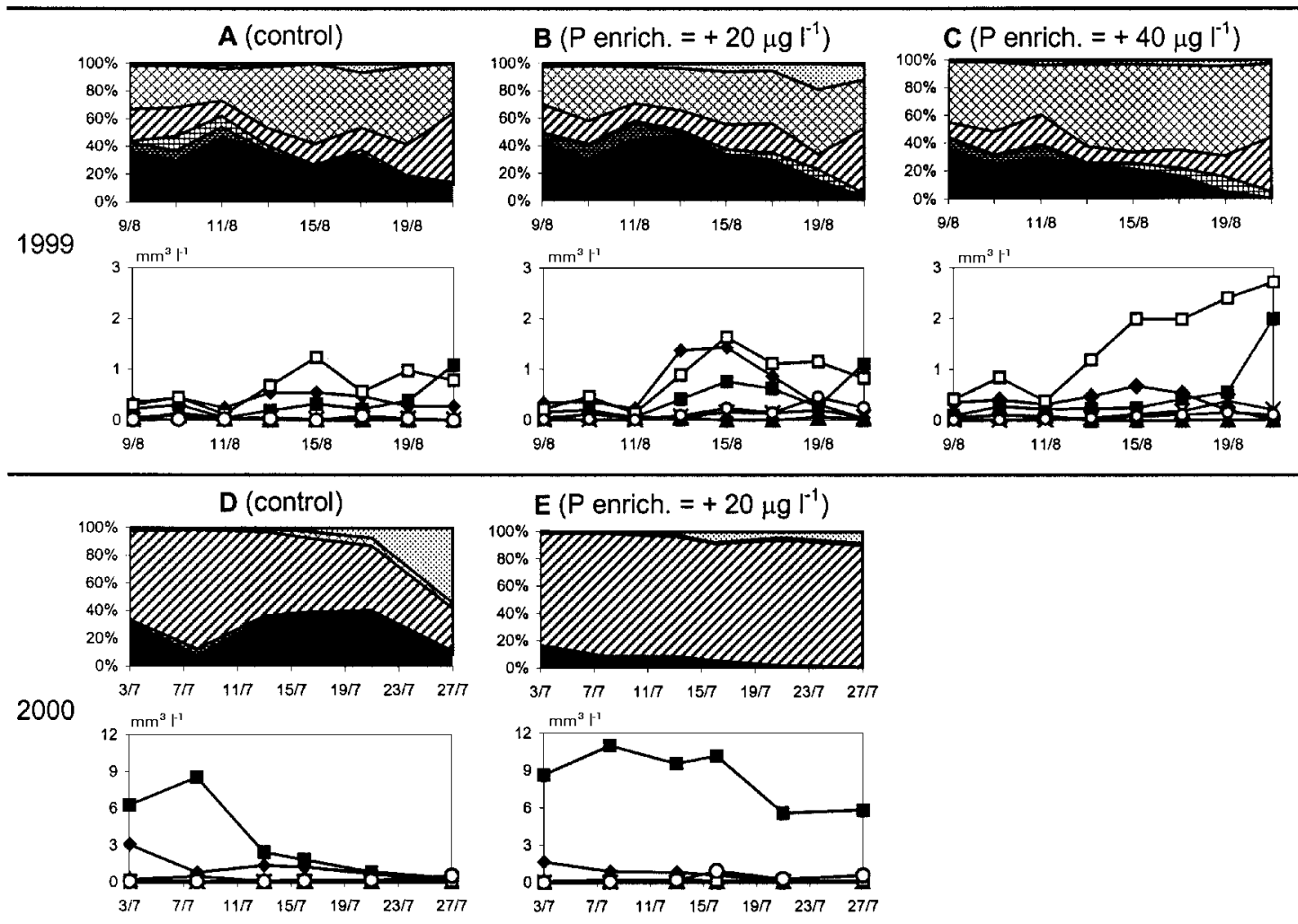

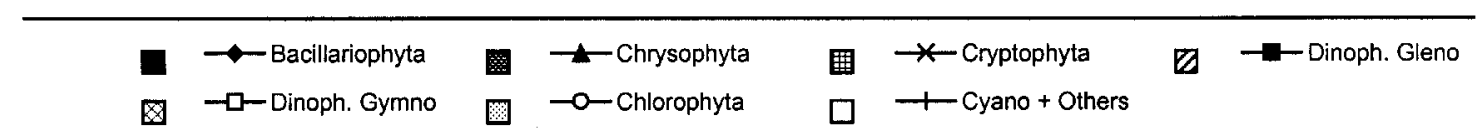

\begin{tabular}{|c|c|c|c|c|c|c|}
\hline$t$ Test (Glenodinium sanguineum biovolumes) & $t$ & $\mathrm{df}$ & $\mathrm{nx}$ & ny & $\mathrm{P}$ & Signif. \\
\hline 1999 enriched pool (B) - 2000 enriched pool (E) & -10.49 & 14 & 10 & 6 & $<0.001$ & $* * *$ \\
\hline 2000 enriched cylinder (B) -2000 enriched pool (E) & -4.85 & 16 & 12 & 6 & $<0.001$ & $* * *$ \\
\hline 1999 control pool (A) - 1999 enriched pool (B) & -1.00 & 18 & 10 & 10 & 0.331 & n.s. \\
\hline 2000 control cylinder (A) - 2000 enriched cylinder (B) & -4.70 & 21 & 11 & 12 & $<0.001$ & $* * *$ \\
\hline
\end{tabular}

Fig. 4. Per cent phytoplankton community composition (based on biovolumes) and absolute values of biovolumes of the main groups or taxa (Dinoph. Gymno= Gymnodinium uberrimum; Dinoph. Gleno= Glenodinium sanguineum) during the experiments carried out in the pools and results of $t$ tests comparing enclosures of different shapes (pools / cylinders), in different years (1999/2000) with and without phosphorus enrichment. 
Tab. 3. Correlations among biovolumes (G. sanguineum and total phytoplankton) and macronutrients (total phosphorus and nitrate-nitrogen). - = not significant; $\diamond=0.01<\mathrm{P}<0.05$ significant association; $\diamond \diamond=0.001<\mathrm{P}<0.01$ highly significant association; $=0.01<\mathrm{P}<0.05$ significant negative association; $\downarrow=0.001<\mathrm{P}<0.01$ highly significant negative association.

\begin{tabular}{|c|c|c|c|c|c|c|c|c|c|c|c|c|}
\hline & \multicolumn{3}{|c|}{1998} & \multicolumn{3}{|c|}{1999} & \multicolumn{3}{|c|}{2000} & \multicolumn{3}{|c|}{2001} \\
\hline & $\mathrm{A}$ & $\mathrm{B}$ & $\mathrm{C}$ & A & $\mathrm{B}$ & $\mathrm{C}$ & $\mathrm{A}$ & $\mathrm{B}$ & $\mathrm{C}$ & $\mathrm{A}$ & $\mathrm{B}$ & $\mathrm{C}$ \\
\hline \multicolumn{13}{|c|}{ G. sanguineum biovolume } \\
\hline $\mathrm{TP}\left(\mathrm{mg} \mathrm{l}^{-1}\right)$ & - & - & $\diamond$ & - & - & - & - & $\Delta \diamond$ & $\infty$ & - & - & - \\
\hline $\mathrm{N}-\mathrm{NO}_{3}\left(\mathrm{mg} \mathrm{l}^{-1}\right)$ & $\diamond \diamond$ & - & - & $\bullet$ & $\bullet \bullet$ & $\bullet$ & - & - & $\diamond$ & - & $\bullet$ & $\bullet$ \\
\hline \multicolumn{13}{|c|}{ Total phytopl. biovolume } \\
\hline $\mathrm{TP}\left(\mathrm{mg} \mathrm{l}^{-1}\right)$ & - & - & $\diamond$ & - & - & - & $\Delta \diamond$ & $\Delta \diamond$ & $\Delta \diamond$ & - & - & - \\
\hline $\mathrm{N}-\mathrm{NO}_{3}\left(\mathrm{mg} \mathrm{l}^{-1}\right)$ & $\diamond \diamond$ & - & $\bullet$ & $\bullet$ & $\bullet$ & $\bullet$ & - & - & - & - & - & - \\
\hline
\end{tabular}

The comparison between control pools and phosphorus enriched pools carried out for the two years provided different results (statistically significant difference in 2000, but not in 1999), confirming year to year variability. The mean of the $G$. sanguineum biovolume measured in the cylindric control in 2000 was found to be significantly different from the one in the control pool. The variations of the main phytoplankton species in the pools in 1999 and 2000 are shown in figure 4 (upper part). In summer 1999, meteorological conditions were bad and phosphorus additions favoured G. uberrimum and a marked increase of the chryptophyte Campylomonas Hill sp., while G. sanguineum did not reach high biovolume values (Tardio et al. 2001, 2003). The potential of this species to develop also within this type of enclosures was observed in summer 2000 , when high initial amounts of $G$. sanguineum were present at the beginning of the experiment and persisted in the $\mathrm{P}$ enriched pool.

Even if a direct comparison between the two types of mesocosms was not possible as a result of the statistical analyses, the analogies between the species, which developed in the shaded cylindric enclosure in 2000 and in the pools during the suboptimal climatic conditions in summer 1999, remain striking.

The results of single classification analyses of variance underpinned important differences among years not only for the meteorological parameters, but also for G. sanguineum (Tab. 2). To make sure that among years differences in $G$. sanguineum and total phytoplankton biovolumes were statistically significant also excluding the variability between enclosure types, the means obtained in the three years when cylinders were used were compared by single classification analyses of variance. The results $(G$. sanguineum biovolumes: $\mathrm{df}=24, \mathrm{~F}=$ $6.84 * *$; total phytoplankton biovolumes: $\mathrm{df}=24, \mathrm{~F}=$ $21.14 * * *)$ confirmed that there were highly significant differences among years, even when only mesocosms of cylindrical shape are considered.

The correlations between $G$. sanguineum and total phytoplankton biovolumes respectively and the macronutrients (total phosphorus and nitrates) is summarised in table 3. Several significant positive correlations with total phosphorus and negative correlations with nitrates could be demonstrated, particular for the enriched mesocosms.

\section{DISCUSSION}

During four years of enclosure experiments we investigated the effects of the limiting nutrient, phosphorus, and of "meteorological forcing" on the phytoplankton of Lake Tovel and particularly the dinoflagellate, Glenodinium sanguineum, once responsible for a spectacular reddening phenomenon.

The results were somewhat complicated by changing objectives in the individual experimental years, since we used different types of mesocosms, the empirical limits due to work with relatively large structures (cylinders) and by the constraints of experimental work conducted under field conditions. However, the analysis of the results obtained in two different types of mesocosms and during four summers of experiments was significant, since it showed clear effects with phosphorus additions.

Differences among years and among enclosure types were significant, suggesting that the two types of enclosures determine differences in the evolution of the phytoplankton and thus cannot be directly compared.

The $\mathrm{P}$ additions were generally followed by an increase in the phytoplankton biovolumes. Thus, total phytoplankton biovolumes could be due to the combined effect of among years and among enclosure type variability. The addition of the limiting nutrient $(\mathrm{P})$ generated interspecific competition. The specific environmental conditions determined the species able to assimilate the nutrient, which became dominant within the phytoplankton community. Meteorological parameters, light climate in particular, were shown to be important variables in determining the successful competition for phosphorus of Glenodinum sanguineum. Nitrogen was observed to limit the development of $G$. sanguineum populations only in conditions forced with phosphorus enrichments.

The positive reaction to phosphorus additions would be consistent with an obligate autotrophy of $G$. sanguineum (Jansson et al. 1996), which was found to lack trichocysts in ultrastructural investigations (Dodge et al. 1987). However, heterotrophic assimilation must be tested by designing specific experiments, before excluding the possibility of mixotrophic behaviour in this dinoflagellate. 
Freshwater red tides, due to dinoflagellates, occur most frequently in waters which are moderately rich in nutrients (meso-oligotrophic; Fukuju et al. 1998). A sufficient availability of phosphorus and nitrogen seems to be important in promoting the blooms. Nishibori et al. (2000) determined high half saturation constant (Ks) values for phosphate and a low optimum N:P ratio for Peridinium bipes f. occultatum. Ikeda et al. (1997) showed that the optimum light intensity for $P$. bipes $\mathrm{f}$. occultatum was relatively high among freshwater phytoplankton. Leitao et al. (2001) commenting on two cases of freshwater red tides in France reported that solar radiance was high in both situations, that ammonia and nitrate concentrations were not low and, that phosphates were almost completely depleted by the blooms suggesting that it plays an important role in its metabolism.

According to Fukuju et al. (1998) reservoirs affected by dinoflagellate red tides in Japan are located in a comparatively warm region, with few pollutant sources, and have basins which have a narrow and deep shape, which are stratified and have water quality ranging from oligotrophic to mesotrophic. Lake Tovel is a comparatively deep lake with a main basin with steep slopes and its summer water renewal rate seems to have increased, with warm surficial waters being lost thorough the outlet and a reduction of the epilimnion (Paganelli 1992). Fukuju et al. (1998) stated that the place of occurrence of red tides varies according to reservoir and time, but many cases occur in the inflow area. This would be matched by the situation that occurred in Lake Tovel, where the highest concentrations of $G$. sanguineum were always recorded in the SW-Bay (i.e. exactly in the part of the lake receiving most of the inflowing groundwater). The springs (mostly submerged) in this part of the lake are fed by a stream which drains one of the pastures were cattle breeding was most developed in the past (Borsato personal com.).

\section{CONCLUSIONS}

From the results obtained in the four years of mesocosm experiments the following conclusions can be drawn:

- Phosphorus is the main nutrient limiting phytoplankton and G. sanguineum production in Lake Tovel;

- G. sanguineum takes advantage of the available P and becomes dominant within the phytoplankton community during the summer when the irradiance conditions are near optimal.

Our observations based on in situ experiments suggested that these conclusions were key aspects regulating the dynamics of the summer phytoplankton of Lake Tovel. The understanding of these driving factors allowed us to generate high $G$. sanguineum densities, comparable to those recorded by Baldi (1941) at the time of the reddening. However no red water could be observed. Therefore, our future objective is to identify environmental conditions "triggering" the carotenoid accumulation. Data available for one of the few model organisms, the green alga Haematococcus pluvialis, suggests that nitrogen, phosphorus and irradiance may be relevant elements in this context (e.g. Hagen et al. 2001).

\section{ACKNOWLEDGMENTS}

Since 2001 our enclosure investigations were carried out in the frame of Work Package 6 (Ecophysiology of G. sanguineum in situ) of the SALTO (Studio sul mancato arrossamento del Lago di Tovel / BEST (Blooms and environment: Science for Tovel) Project supported by the Autonomous Province of Trento by means of its Research Funds. Previous in situ experiments were sponsored by the Adamello-Brenta Natural Park. The installation of the cylindric enclosures has been possible thanks to the precious help of the Scuba divers of the Fire Brigade of Trento.

\section{REFERENCES}

Aregger Perini, S. E. 1968. Tovel (Trento). Un patrimonio di alghe. In: Italia Nostra, Roma 1968, 60: 92-93.

Baldi, E. 1941. Ricerche idrobiologiche sul Lago di Tovel. Mem. Mus. St. Nat. Ven. Trid., 6: 1-279.

Berman-Frank, I., T. Zohary, J. Erez \& Z. Dubinsky. 1994. $\mathrm{CO}_{2}$ availability, carbonic anhydrase and the annual dinoflagellate bloom in Lake Kinneret. Limnol. Oceanogr., 39: 1822-1834.

Bolognini, N. 1877. Salita alla Cima Roma (300 m circa) il 26 agosto 1875. In: Annuario SAT, Milano (1877): 69-82.

Cantonati, M., M. Tardio, M. Tolotti \& A. Boscaini. 2002. Caratteristiche di mesocosmi utilizzati per lo studio del fitoplancton. Studi Trentini di Scienze Naturali - Acta biologica, 78(1): 167-172.

Cordella, P., A. Miola, R. Trevisan, E. M. Cappelletti \& A. Paganelli. 1981. Concentrazioni di fosforo e di azoto inorganico in tre laghi del Nord Italia. Atti I Congresso $\mathrm{Na}$ zionale della Società Italiana di Ecologia, Salsomaggiore Terme (PR), 21-24 ottobre 1980, Ed. Zara, Parma, 1981: 117-121.

Corradini, F., G. Flaim \& V. Pinamonti. 2001. Five years of limnological observations on Lake Tovel (1995-1999): some considerations and comparisons with past data. Proceedings AIOL, 14: 209-218.

Dodge, J. 1970. Report of limnological investigation of Lake Tovel (Trentino, N. Italy). St. Trent. Sc. Nat., 47: 91-94.

Dodge, J.D., P. Mariani, A. Paganelli \& R. Trevisan, 1987 Fine structure of the red-bloom dinoflagellate Glenodinium sanguineum, from Lake Tovel (N. Italy). Algological Studies, 47: 125-138.

Eccel, E. 2000. Commento all'annata meteorologica 1999 in Trentino. Natura Alpina, 51 (1): 19-28

Fuganti, A. \& G. Morteani. 1999. La storia del Lago di Tovel in base ai sedimenti della Baia Rossa (Trentino). Geol. Tecn. e Amb., 3: 1-12.

Fukuju, S., T. Takahashi \& T. Kawayoke. 1998. Statistical analysis of freshwater red tide in japanese reservoirs. Wat. Sci. Tech., 37 (2): 203-210.

Gerosa, V. 1966. La natura chimica delle sostanze che provocano l'arrossamento del Lago di Tovel. 2a Nota - Cromatografia su strato sottile. St. Tr. Sc. Nat., 43 (1): 145-158.

Hagen, C., K. Grunewald, M. Xylander \& E. Rothe. 2001. Effect of cultivation parameters on growth and pigment biosynthesis in flagellated cells of Haematococcus pluvialis. J. Appl. Phycol., 13: 79-87. 
Halac, S., M. Felip, L. Camarero, S. Sommaruga-Wögrath, R. Psenner, J. Catalan \& R. Sommaruga, 1997. An in situ experiment to test the solar UVB impact on plankton in a high altitude mountain lake. I. Lack of effect on phytoplankton species composition and growth. J. Plankton Res., 19: 1671-1686.

Hein, M. \& B. Riemann. 1995. Nutrient limitation of phytoplankton biomass or growth rate: an experimental approach using marine enclosures. J. Exp. Mar. Biol. Ecol., 188: $167-180$.

Hoek, C. van den, D.G. Mann \& H.M. Jahns. 1995. Algae. An introduction to phycology. Cambridge University Press: $627 \mathrm{pp}$.

Ikeda, T., Y. Ohnishi, K. Hatamochi, I. Yuzaburo \& A. Kawai. 1997. Physiological characteristics of a dinoflagellate Peridinium bipes f. occultatum forming freshwater red tides in the reservoirs. Rikusuigaku Zasshi, 58 (4): 395-403.

I.R.S.A. - C.N.R, 1994. Metodi analitici per le acque. Istituto di Ricerca sulle Acque, Quaderni. Roma.

Jacobsen, A., J.K. Egge \& B.R. Heimdal. 1995. Effects of increased concentration of nitrate and phosphate during a springbloom experiment in mesocosm. J. Exp. Mar. Biol. Ecol., 187: 239-251.

Jansson M., P. Blomqvis, A. Jansson \& A.-K. Bergström. 1996. Nutrient limitation of bacterioplankton, autotrophic and mixotrophic phytoplankton, and heterotrophic nanoflagellates in Lake Örträsket. Limnol. Oceanogr., 41(7): 1552-1559.

Leitao, M., L. Ten-Hage, G. Mascarell \& A. Couté. 2001. Peridiniopsis corillionii sp. nova (Dinophyta), une nouvelle dinophycée d'eau douce de France responsable de marées rouges en rivière. Algological Studies, 102: 1-15.

Lorenzen, C. J. 1967. Determination of chlorophyll and phaeopigments: spectrophotometric equations. Limnol. Oceanogr., 12: 343-346.

Lund, J.W.G., G. Kipling \& E.D. LeCren. 1958. The inverted microscope method for estimating algae number and statistical basis of estimating by counting. Hydrobiologia, 11 : 143-170.

Marchesoni, V. 1959. La Val di Tovel e il "Lago Rosso". Natura Alpina, 10: 37-76.

Margalef, R. 1983. Limnologia. Ediciones Omega: 1009 pp.

Mitchell, S.F. \& T.J. Malthus. 1984. Evaluation of a shortterm bioassay for nitrogen limitation of phytoplankton. Verh. int. Ver. Limnol., 22: 250-253.

Nishibori, N., T. Nishijima \& Y. Hata. 2000. Effects of phosphate, calcium and B-group vitamins on the growth of
Peridinium bipes f. occultatum (LINDEM.) LEF. Nippon Suisan Gakkaishi, 66 (5): 812-817.

Oetheimer, C. 1992. La foresta sommersa del Lago di Tovel (Trentino): reinterpretazione e datazione dendrocronologica. St. Tr. Sc. Nat., Acta Geol., 67: 3-23.

Paganelli, A., P. Cordella, R. Trevisan \& E. M. Cappelletti. 1981. Il Lago di Tovel (Trento) e sue modificazioni ambientali. Proc. Congr. Naz. Soc. It. Ecolog., Salsomaggiore Terme (PR), 21-24 ottobre 1980. Ed. Zara: 87-93.

Paganelli, A. 1992. Lake Tovel (Trentino): limnological and hydrobiological aspects. Mem. Ist. ital. Idrobiol., 50: 225-257.

Park, H.D. \& H. Hayashi. 1993. Role of encystment and excystment of Peridinium bipes f. occultatum (Dinophyceae) in freshwater red tides in Lake Kizaki, Japan. J. Phycol., 29: 435-441.

Rodriguez, S., A. Couté, L. Tenhage \& G. Mascarell. 1999. Peridiniopsis durandi sp. nova (Dinophyta), une nouvelle Dinophycée d'eau douce responsable de marées rouge. $\mathrm{Al}$ gological Studies, 95: 15-29.

Rott, E., 1981. Some results from phytoplankton counting intercalibrations. Schweiz. Z. Hydrol., 43: 34-62.

Sokal, R.R. \& F.J. Rohlf. 1981. Biometry. Second edition. Freeman and Company, New York: 859 pp.

Tardio, M., M. Cantonati \& M. Tolotti. 2001. Condizionamento meteorologico nello sviluppo del fitoplancton del Lago di Tovel (Trentino): indicazioni da ricerche in mesocosmi. Proc. XI Congresso Nazionale della Società Italiana di Ecologia, Sabaudia, 25: CD-rom.

Tardio, M., M. Tolotti, G. Novarino \& M. Cantonati. (2003). Ecological and taxonomic observations on the flagellate algae characterising four years of enclosure experiments in Lake Tovel (Southern Alps). Hydrobiologia: (in press).

Tolotti, M., M. Cantonati M. \& F. Corradini F. 1999. Investigating dinophyte blooms with P-enriched enclosures in a mountain lake (Lake Tovel, Southern Alps, Italy). Proc. 8th International Conference on the Conservation and Management of Lakes, Copenaghen, 2: S16B-5.

Tomasi, G. 1989. Dall'immaginario al plausibile. Natura Alpina, 40: 1-72.

Utermöhl, H. 1958. Zur Vervollkommung der quantitativen Phytoplankton Methodik. Mitt. Internat. Verein. Limnol., 9: 1-39.

Vinebrooke, R.D. \& P.R. Leavitt. 1999. Differential responses of littoral communities to ultraviolet radiation in an alpine lake. Ecology, 80 (1): 223-237.

Wilcox, G. \& J. DeCosta. 1982. The effect of phosphorus and nitrogen addition on the algal biomass and species composition of an acidic lake. Arch. Hydrobiol., 94 (4): 393-424. 